CIRR XXI (73) 2015, 109-129

ISSN 1848-5782

UDC 342.7:396 (496.5)

DOI 10.1515/cirr-2015-0013

\title{
Am I an Active Citizen? \\ Women's Narratives of Citizenship Practices in Albania
}

Eriada Cela

\section{Abstract}

This study explores the topic of citizenship as related to the practices of twelve Albanian women. This research utilizes literature on gender and citizenship as a framework for comparing and analysing the narratives of women who exert their political citizenship through civil society and governmental political bodies. First, this study explores the ways the interviewees perceive citizenship while analysing women's narratives to get at their spoken and unspoken specificities. Secondly, it discusses their conceptualisations of themselves as active citizens and analyses how their expressed perceptions relate to their identification as political actors with regards to their identities as women. Thirdly, it analyses issues of relevance to women's engagement as active citizens as they appear from women's individual experiences of citizenship in the narratives. This research focuses on the way interviewed Albanian women perceive themselves in relation to their citizenship and what their experiences as citizens say about their self-identification as agents with a say in the issues that affect their lives.

\section{KEY WORDS:}

citizenship practices, women, narratives, Albania, civil society 

citizenship

The concept of citizenship in this paper is used in two forms. In the first part of the narratives, which refer to the beginning of the interviews, no emphasis is put on any particular aspect of citizenship, and respondents are allowed to make any possible correlations to the citizenship concept. The second way the concept of citizenship is used in this paper is through the aspect of political citizenship, of which the concept of active citizenship is part. The social and civil aspects of citizenship are not totally excluded from the analysis, but they are less present as a result of the emphasis placed on the political aspect of citizenship, especially where the paper focuses on women's active citizenship.

As broad a term as it is, the concept of citizenship is viewed and narrated in different ways by the respondents, whose perspectives vary according to their personal experiences and characteristics. Its complexity and wide degree of entailments are the focus of this research, where I analyse perceptions and experiences as narrated by my interviewees. The question of how women in Albania perceive themselves as citizens and how they experience active citizenship is a means by which to explore the notion of citizenship, comparing women's narratives to the literature on gender and citizenship. The interviews are analysed through the lens of feminist critiques of citizenship regarded as a traditionally male domain.

\section{Theoretical background: What is citizenship?}

According to Voet, citizenship can be seen as the relationship between a state and a citizen as well as the political relationship between citizens (Voet 1998: 9). The influential scholar of citizenship theory in Britain, T.H. Marshall, has defined citizenship as a "status bestowed on persons who are full members of a community" (Marshall 1950: 14). The key elements in Marshall's concept of citizenship are membership of a community, 
equality of the members of that community, and rights and obligations that result from membership. The political aspect of citizenship as explained by Marshall might also be recognised as including duties apart from rights when referring to political participation as part of citizenship. In this respect, the "right to participate in the exercise of political power, as a member of a body invested with political authority or as an elector of the members of such a body" (Marshall 1950: 10), explicitly states the obligation of citizens to employ their political capacity.

As Lister justly argues, rights and responsibilities are closely linked in the "citizenship equation". In her view, "...the question is: what is the appropriate balance and relationship between the two and how does that balance reflect gender and other power relations?" (Lister 1997: 31). Other definitions of citizenship are expressed in terms of dichotomies such as active/passive and public/private (Turner 1990: 209). Since gender is not properly reflected in the traditional dimensions of citizenship, feminist theory requires the integration of gender into citizenship theory in order to properly understand the concept of citizenship within the dynamic of gender relations. Two models for including gender in political citizenship have been introduced: through the "politics of difference", which places difference before equality but risks freezing group identities as women, (Young, 1990,Mouffe 1992), and through the "politics of presence", such as gender quotas (Phillips, 1995).

\section{Methodology}

The semi-structured interviews aim to discover women's perceptions and practices of citizenship as well as their identification with political potential. Based on the limited selection of interviewees, the findings and realities as discovered from the respondents are not indicative of all Albanian women's experiences and perceptions, so far as issues such as education, class, religion, ethnic minorities and rural-urban distinctions remain unexplored. The interviews were conducted with women from Tirana and Elbasan who are part of civil society and women politicians, which are seen as two categories of women that, according to citizenship 
and gender literature, fit the description of women as active citizens on the basis of their political citizenship exertion. The selection of interviewees as active citizens was only literature-based, however, because during the interviews women were questioned about their own perceptions of themselves as citizens and since the concepts of 'citizenship' and 'active citizenship' entail broad meanings, the informants' views of their being active citizens varied accordingly.

The first group of informants as part of civil society consisted of eight interviewees who belonged to three categories: women working in women's non-governmental organisations, women working in humanitarian NGOs, and women who undertook volunteer work in any of these two entities. The second group included four women who are involved in local and central governmental bodies, and thus women who are part of the decision-making process. The interviewees are aged from their twenties to fifties, but women aged from twenty to thirty comprised the greater number of informants, and there were only two women in their forties and one in her fifties. The presence of such a wide range of respondent ages is due to the perceptions and experiences of women who had experienced working and living during state-socialism compared to those who did not. It is important to point out that even though the differences between the interviewees are used as fields for comparisons, this study does not primarily aim to compare women's experiences. When using interview quotations, pseudonyms are used instead of the respondents' real names, even though some, especially women politicians, willingly offered use of their real names in this research. Since pseudonyms were used for most of the respondents, however, I decided to do the same for those women who offered to be recognisable, thus being consistent throughout the study.

In feminist research and knowledge production, the empowerment of women and the equality of the research relationship are two key concepts that cannot be ignored by the researcher (Millen, 1997). The empowerment of women in this study is realized by the fact that through the interviews a particular group of Albanian women are given voice to speak about their specific experiences as active agents in their society. 


\section{Citizenship as conceptualised by women}

A complex and multi-layered concept, citizenship is a notion that is not part of daily debate, and therefore people are not often confronted with this topic unless their engagement in different citizenship activities makes them consider their work as part of their citizenship. Thus, when asked to think about the concept and to share their perceptions, some of the women also shared the fact that the interview served as a moment of reflection in their lives about the meaning they can give to citizenship and, particularly, their own citizenship as related to their identities as women.

All respondents consider citizenship to be closely connected to rights and duties. They all associate citizenship with life within a specific community where, in their opinion, citizens are expected to offer their contribution through their engagement in different issues for the benefit of community interests in interaction with other citizens. These two associations made by respondents are interrelated in their concerns about the rights and duties discourse as the basis of equality between men and women in the civil, political and social spheres, which is the primary basis for women's full citizenship. Community interests fall into the duties discourse so far as those interests are supposedly reached through women's involvement as citizens on the basis of their citizenship obligations. In these terms, the respondents made no particular reference to their gender as a distinguishing factor of specific rights or obligations as persons.

The next most frequently expressed association of citizenship perceptions (for 10 out of 12 interviewees) was related to the issue of representation as part of political engagement. The respondents connected this aspect of citizenship to the accountability of political representatives as well as their own obligation to make the representatives accountable for their expected duties. Most, both politicians and non-politicians, consider the small number of female political representatives in Albania to be a problem, making reference to women representatives as better leaders or as more willing to address women's issues than male representatives. As theoretically coined by feminist literature, this concern is closer to the concept of the "politics of difference" than the "politics of presence". However, both these concepts are present in the way women tackle 
women's representation in politics as far as they require both women to be present in the political domain, as well as women to act as agents for women's issues.

Many (nine of the respondents) also referred to citizenship as a role and mission. Citizenship as a role, in their opinion, is equally attributed to all citizens, however, there is differentiation between citizens in terms of activities, thus clearly distinguishing between active and non-active citizens. Three of these nine respondents held citizens responsible for their reluctance to act as citizens and fulfill their citizenship role, while the other six were more comprehensive and willing to justify an inability to act as active citizens. Both women over and below the age of thirty brought up the totalitarian regime as one of the factors affecting citizen passivity.

Another common thread of citizenship perception among the interviewees was the positioning of citizenship as a contract between the state and individuals, where both parts have respective responsibilities. In this respect, all the respondents who expressed this link to citizenship referred to citizens in gender-neutral terms, claiming no gender-based difference. Some (five) even said they consider citizenship as consisting of standards that have to be reached, as a way of living with regard to certain cultural norms. A few connected citizenship with geographical belonging and, what is more, as identity or one of its components. Two of the respondents, one a politician and the other a humanitarian NGO worker, expanded the citizenship notion by making reference to European citizenship as part of Albania's process of accession to the European Union.

Surprisingly, the social aspect of the concept was missing in women's narratives of citizenship as a general concept. The fact that the interviewees did not mention any feature of social rights is an indicator of the Albanian state's currently insufficient provision of welfare regimes, particularly for women. Most of the above associations with the concept of citizenship were made while women were making reference to citizenship in general terms without personalizing or contextualizing it; no particular gender divisions were made and none of the interviewees referred to citizenship as a gendered concept. Given the literature on the gendering of citizenship, these narratives can be classified as being either gender-blind or genderneutral. I view them as gender-neutral rather than gender-blind in so far 
as their reference to citizenship was not in exclusionary terms but neutral to the gender of citizens. I interpret their gender neutrality in their general expressions of citizenship as the result of their recently gained or even previously existent awareness of women's acceptance as equal citizens without the need for differentiation. Obviously, as part of civil society or political bodies, the interviewees may have been in some way influenced by their contact with current feminist debates through different organised trainings or events, however, I do not deny the possibility of their genuine attitude towards a gender-neutral citizenship.

\section{Citizenship as entitlement to rights and obligations}

One of the most recurrent answers in the interviews, women's conceptualisations of rights and duties, is closer to two of the aspects of citizenship outlined by T. H. Marshall: civil and the political. As already mentioned, the respondents did not bring up the social aspect of citizenship rights. Their self-identification as citizens was not articulated in terms of second-class citizenship in spite of these women's experiences as such at some point in their lives. The close connection of citizenship to rights and duties can be linked to the definition of citizenship as a status and practice. In these terms, rights are obtained from the ownership of the citizenship status and duties or obligations stem from and are operationalized in the practice of citizenship. All the respondents made explicit reference to citizenship as a status that entitles citizens to rights as well as obliges them to abide by rules and obligations as unavoidable components of citizenship. The "rights and duties" term seemed to be used more during the first interviews as a cliché, but as the rest of the interviews were conducted, I understood the reason the respondents perceived the two as closely interrelated.

Especially in the cases where the interviewees referred to citizens as "people with a keen eye on what goes on around them", as Suzana, a local government official phrased it, rights and duties were expressed as being chronologically connected and no one mentioned rights without later relating them to duties. First respondents mentioned eligibility for 
certain rights and later they introduced the obligations corresponding to the particular rights. For example, according to Marsida, a young teacher and volunteer in a social movement, "you have the right to live in a clean environment, but you can in no way escape the obligation of caring about it". Rights and duties as part of citizenship were also described as creating a chain reaction in terms of the impact that one might have on the other, thus being very closely interrelated. To be more specific, as Anisa, a regular follower of local government events in Elbasan, explains, no duties can be performed unless the rights corresponding to that duty are respected:

As a citizen, I feel obliged to choose my representatives and to participate in monthly meetings where important matters are discussed and decided. If my right to be properly informed about my representatives or meeting dates of the municipality meetings is not respected because information is not properly disclosed, I cannot fulfill my citizenship duties.

In this case, placing the right to information as the condition upon which to base her own actions as a citizen, Anisa links the right to be informed to her duties as a voter and local participant.

The kind of rights expressed during the interviews consist predominantly of rights that are guaranteed by law on the basis of citizenship and, as already mentioned above, the respondents see themselves as being in an individual relationship with the state. Respondents considered themselves as eligible for all types of rights emerging from their equal citizenship status without feeling excluded from it, at least from the perspective of laws and regulations, even though during the interviews they all made reference to discrimination, mistrust or obstacles they had experienced at some point in their lives primarily because of their sex. These experiences had not affected the women's perceptions of citizenship, however, and they do not describe viewing themselves as second-class citizens.

Voting was one of the citizenship rights to which almost every interviewee made reference. Many respondents, however, referred to the process of voting as a citizenship activity that is the exercise of duties and of rights at the same time. For Elona, a student volunteer in a social movement, the 
right to vote is also a major obligation as an adult citizen: "Now that I am over 18, voting is my major requirement as a citizen, so I am obliged to use the power of suffrage. If I don't vote, or other adult people don't vote either, most probably offices will be run by the wrong people; this is why I feel obliged to utilize my right to vote". Noticeably, even though expressed in terms of duties, voting is also recognised as the tool for exerting one's political will as citizen, as Brunilda pointed out: "Voting is the primary means of expressing my citizenship first, and of having my voice heard second". Along the same lines, the majority of the interviewees considered the voting process as very important and they identified power and agency in the exercise of their own will as citizens through voting. Being in the role both of electors and the elected, some of my interviewees immediately related the process of voting to their recognition of the need for more women representatives.

Working was also described simultaneously as both a right and duty. As Berta, a worker in an international NGO in Tirana, put it, she considers work as both her right as a woman and her duty as a citizen, in order to be economically independent. Vera, aged 55, also described the same perception of work as simultaneously a right and duty. Interestingly, she also perceived work as both a right and duty during the previous regime, since she had experienced being employed during the state-socialist regime as well. Currently a politician, Vera said that she perceives her current work as a personal obligation rather than as a requirement by state, as it used to be under the previous regime for women. She relates work as a citizenship right to her identity as a woman, stating that as a woman, she has the same right as men to be part of the labour force.

\section{Women and active citizenship experiences}

In this section issues that emerged from the women's narratives of their experiences as active citizens are presented and analysed. Given the complexity of the term 'citizenship', even the concept of active citizenship itself is debatable so far as the nature of activities belonging to the category of "active citizenship" are concerned. As is by now evident, 
however, of the three aspects of citizenship noted by T. H. Marshall, the concept of active citizenship is political. The importance of studying and analysing variations in the active citizenship experiences of women in Albania therefore lies in discovering women's specific experiences as active citizens first, and in their positioning as agents of change second, whether this is within the existing political system or in civil society. As Voet and Lister both point out, the field of carrying out citizenship activities is broad and women can promote themselves as agents of change through their involvement in different activities (Voet 1998, Lister 1997).

When asked to personalise the citizenship concept and think of themselves as citizens, the interviewees almost always related citizenship to their gender, profession, educational background, political context, family or society as crucial factors that are inseparable from their perception of citizenship. What was easily distinguishable in most of the interviews was the fact that most women positioned themselves as individuals who feel obliged to act and take responsibility, thus reinforcing the idea of perceiving citizenship as a role that involves action and framing themselves as potential actors of change, the degree of which varies according to their personal or institutional position. When contextualizing or personalizing their narratives, however, they became more specific, and questioned and explained citizenship rights and duties with reference to real situations of which they were either aware or, most often, had experienced in their own lives.

\section{Citizenship as women's agency}

While speaking about their personal experiences as active citizens with particular reference to citizenship as a practice, the respondents introduced the concept of agency in terms of their ability and opportunity to bring about change. Agency, as Birte Siim (2000) claims, lies at the heart of the theorization and politics of women's citizenship. The interviewees often made reference to agency as emerging in response to current conflicts or situations in need of immediate action. Even though at some other stage of the interviews some had considered active citizenship a 
continuous lifestyle, they connected the issue of agency with specific difficulties they came across at some point in their lives or activities. Most interestingly, the problems mentioned by the interviewees when illustrating cases of their agency as active citizens, also prompted their initial interest or particular field of activities. This does not limit their activities to one single nature, however, it only indicates that the first recollections of their own agency were related to their typical activities as active citizens either at the individual or organisational level.

Berta, a woman working with a humanitarian NGO in Tirana, relates the degree of agency to personal involvement first and networking second.

In my opinion, there are two forms of being an active citizen: one can try to do something individually or can cooperate with other people. For example, if part of the street was damaged, I would call the municipality department in charge of repairing it. This action does not change the world, but at least it improves the situation. The second form of active engagement is when we look for networks and try to find solutions together. In my opinion, both cases are fine as long as we do not sit down and wait.

Brunilda, the manager of an international NGO local office in Elbasan, offered a very personalised narrative to her conceptualisation of citizenship as duties through which she exercises her agency as citizen. Being in a managerial position, she closely connected her overall performance within her work as part of her duties as a citizen:

Since many things I do cannot be separated from my job activities, I feel inclined to fulfill my obligations as a citizen even within my work. For example, I am attentive to bringing about positive changes and offering opportunities to gifted and hardworking people, particularly women, without becoming part of compromises that might corrupt my position as a leader, which I also connect to being a citizen. Meanwhile, being aware of the small number of female managers in Albania, I also feel morally obliged to portray my role as a good citizen and efficient manager to other people in order to show that women also have the ability to perform in such positions. 
This quote opens two points for discussion. First, as personalised activities, it shows how one's duties as citizens are perceived as being broad enough to encapsulate other variations of duties at the same time. Here, Brunilda frames her concerns about being correct and offering space to those she sees as the right people as part of her citizenship duties. Other respondents who considered this as part of being good citizens, also made the same reference to citizenship as a rightful part of one's job. Secondly, Brunilda makes reference to the glass-ceiling phenomenon, in her concern about offering more space to other women through her position as well as by using her achievement and good job performance as an example of women as efficient managers.

The concept "good citizen" as employed by Brunilda above, however, points out her conceptualisation of a "good citizen" as involved with both political and non-political actions. One finding thus concerns some of the women's conceptualisations of citizenship and their views of active citizenship as consisting of different unwritten obligations that are not always closely related to political issues. They view citizenship as a concept that encapsulates a variety of actions. Other interviewees made the same link to citizenship obligations of this kind through examples such as offering a seat to an elderly person (Berta), crossing the road at the white stripes and following eating etiquette properly (Enkeleda), disposing of litter in the right place (Marsida) and other similar activities that attribute meaning in daily life events to the concept of citizenship.

At least in terms of perceptions, most of the interviewees associated their personal relationship with citizenship with their engagement in activities on either a personal or broader level. Most interestingly, some separated citizenship practices, framing them as belonging to two different categories: activities consisting of minimum and often essential obligations, and more demanding activities that require a certain level of awareness, intention and ability to undertake a particular action. This division between minimum activities and other more demanding actions corresponds to Marshall's distinction between "compulsory" duties and "vague" duties. The process of differentiation between citizenship activities is an indicator of the fact that the respondents' considerations of active citizenship exceed the above-mentioned conceptualisation of citizenship as simply a way of living with respect to certain rules and obligations. 
This differentiation is significant in making a difference between simply the required actions as a citizen or standing out through extended interest and activity. As Anisa, quoted here, explained, she does not consider herself an active citizen just because she pays her taxes on time. "On the contrary, the moment I ask what happens to the taxes that I regularly pay, things are different because I do not stop at the level of doing the minimum required of me as a citizen." The same idea of differentiating between activities was described by Elona, who as a student felt that her involvement in extra-curricular activities, especially those related to her volunteer work with a social movement, were a way of separating being 'just a student' and a student that at the same time is an active citizen.

\section{Am I an active citizen?}

Rian Voet's argument about women and their identification as political agents is that women cannot be active citizens in their communities or beyond if they do not first of all identify themselves as political actors (Voet 1998: 142). Not all the interviewed women described such open personal identification with political potential, however, even though they described a need for this in broader terms when referring to other women and the importance of their engagement in political issues or volunteer work. When speaking about citizenship obligations as a component part of being a citizen, some of the interviewees started to speak about their own responsibility to contribute as citizens to improving various conflicting or problematic situations. Therefore, an important finding of my research is that through their own narrations, women associated citizenship with active citizenship. In order to differentiate between citizenship and active citizenship, Ruth Lister's distinction of terms is helpful, as she uses different verbs to describe the two: to be a citizen and to act as a citizen. So, according to Lister," [t]o be a citizen, in the legal and sociological sense, means the enjoyment of the rights of citizenship necessary for agency and social and political participation. To act as a citizen involves fulfilling the full potential of the status. Those who do not fulfill that potential do not cease to be citizens" (Lister 2003, 5). 
So, this theoretical framework distinguishes between citizens in terms of activities, and being called an active citizen based precisely on the performed activities. The fact that all my respondents related their own citizenship indicates that their perceptions of citizenship are linked to their active citizenship potential. The interview questions about women's active citizenship belonged to two levels: the conceptual level and the actual activity undertaken.

According to most of the narratives in the interviews, citizenship activities under the framework of good or active citizenship were all related to the undertaking of responsibility and acting in the best personal or collective interest. Many of the respondents willingly enumerated actions taken in their daily life as part of what they call active citizenship. During this part of their narrations, however, the interviewees seemed to feel much more unobstructed when listing the activities of an ideal citizen rather than their own activities. Apparently, it was easier for many of them to express this in impersonal terms when answers about the activity level were required.

In order to relate this research to Voet's argument about women as active citizens and their necessary identification as political actors I tried to discern hints from my interviewees' narratives. When speaking about citizenship in general, most described personalised action and articulated the need for agency. This is a clear sign of their concern with political engagement, either through civil society, communitarian action or participation in decision-making bodies.

\section{Group identification as women}

Women's general views on citizenship as entitled to rights and duties were described in two ways. This was first through the conceptualisations of rights and duties as applicable to them as citizens: thus making no particular reference to their gender. Secondly, the respondents openly pointed out that as women they have certain rights or duties. In this case, the relationship to gender in their narratives was described either as simply 
a way of identifying with other women or as a means to point out the difference that in their opinion lay in the particular citizenship situation. The concept of women's equality as citizens with reference to male citizens was not always openly spelled out, however, the idea of equality often appeared as the basis for rights eligibility as well as the grounds upon which all respondents required themselves, as well as other citizens, to be responsive to their obligations as citizens.

Most respondents were demanding in their attitude toward other female citizens when addressing the topic of duties and obligations, especially when referring to women's interests. My argument is that group identification as women becomes more prominent when the common interests of women are at stake, in either the case of rights or duties, especially when action for change is required. As Tatjana, the head of a women's organisation in Tirana, put it: "I always try to write newspaper articles in reaction to events within the country or beyond that negatively affect women's lives and situations, but I cannot cover all possible topics. I think that all women who can write such articles should have the feeling of responsibility and should react as soon as possible whenever it is so needed". In this case, Tatjana refers to writing as an active citizenship activity, and through her demanding attitude that other women write more about their common issues she undertakes active citizenship action based on her identification with other women.

Another instance when the respondents related active citizenship to addressing group issues as women was when speaking about active citizenship as channelled into involvement with governmental decisionmaking bodies. Some described concern and discontent regarding the actual political situation in Albania and many of the interviewees openly stated the need for more women to be present as well as actively engaged in politics. Along these lines, the interviewees who brought up this issue always referred to political involvement as belonging to the public sphere, and to women as a homogenous group, disregarding probable differences.

The seven interviewees that mentioned women's need for engagement in decision-making processes also brought up the quota system as one of the components that have an impact on women's access to this aspect 
of political citizenship. All referred to women's involvement in politics as one of women's citizenship rights, but only three considered the quota system as the best temporary solution to the problem of women's underrepresentation in the political domain. On the other hand, the other four respondents described concerns about women's quotas as "facilitators" of the process of women's political engagement. As Ledia put it, "I would want more and more women to be involved into politics, but if they get there through quotas, it would be like they make it into politics precisely because of quotas". In both cases, however, all seven women who made reference to the quota system emphasised the need for women's identification with politics as well as recognising the existence of difficulties women face when intending to be part of decision-making bodies.

In this respect, the respondents' identification with other women as part of their group identity was accompanied by their expression of the necessity for more women to be present as political leaders in order for women's issues to be more properly and seriously addressed. Interestingly, most of the seven respondents who made reference to this issue also seemed to believe in women's greater ability to lead and make politics, which apart from pointing out their existing identity as women, also shows that they believe in essential gender difference as now described in different styles of leadership.

\section{Further aspects of relevance to women's active citizenship}

Based on the interviewees' perceptions of citizenship as closely connected to engagement in either individual or communitarian issues through writing, networking, lobbying and other types of activities that aim to foster change, it is evident that the common denominator in these narratives is the connection of citizenship with the meaning of active citizenship. The personal degree of commitment to citizenship actions was variable, however, and it often depended on other decisive factors in the lives of the respondents. Issues of relevance to women's active 
citizenship as discussed in this section can be regarded as applicable to the interviewees who articulated them, as well as beyond, so that these issues can be considered aspects of importance in the engagement of all women as actors in societies sharing similar features. It is noteworthy that the issues of relevance to women's active citizenship engagement are many, especially considering the political context in post state-socialist countries.

One issue that many of the respondents were concerned about is related to the lack of proper networking within their environs. As Ledia pointed out, networking is a very important factor that affects the organisation of a good level of citizenship activities: "There are certain citizenship activities that all citizens can perform with a bit of desire and effort. On the other hand, there are also other much broader issues that affect the interests of more than one single individual, but which can also be resolved much more easily if all citizens group together and find common solutions." In these terms, the lack of networking and cooperation between citizens is detrimental to the outcome of common citizenship activities. The lack of networking is related to different issues, some of which are specific to Albania as well as other post state-socialist countries.

Even within Albania itself there are differences in terms of networking, however, which are based on particular situations. For example, Anisa, a worker in a humanitarian organisation in Elbasan, complains about the lack of networking and feels that she is in a disadvantaged position even when wanting her neighbourhood litter to be collected more often by the municipality machines during summer time. Her disappointment in this context is related to the reluctance of other citizens in her neighbourhood to be more self-organised and arrange their problem in cooperation with one-another. The issue of networking in this case is related to other features that affect citizen activities, especially women's actions as such. One of the regional factors affecting women's engagement as active citizens is related to the passive mentality, inherited by the state-socialist regime that left no space for individual activities.

Another important element that needs to be mentioned regarding women's activities as actors in civil society is their field of engagement. As already mentioned, the first recollections women made when asked 
to share their activities as active citizens were related to their immediate spheres of engagement. For example, a student, Elona recalled employing her agency within the social movement when one of her university professors was accused of being corrupt; a mother of two, Suzana mentioned the influence she and other parents had in the municipality meetings for the construction of a small park in their neighbourhood; the head of a women's organisation, Tatjana, brought up the lobbying she undertook in cooperation with other women working in women's NGOs for the inclusion of quotas for women's participation as candidates in the elections.

This does not mean that the activities of the women were limited to one activity. It has to be pointed out, however, that their agency is very closely connected to their field of engagement, which suggests two different interpretations. First, such framing as typically women's activities might reduce the importance of women's agency, which apart from denying the importance of women's activities, reduces women's capacities to their immediate actions only. Second, it might imply that these are not real citizenship activities insofar as they are being paid for them, and are thus taking the action in return for personal earnings. As Tatjana, who is the head of a women's organisation in Tirana, argues however, it is easier for her and her colleagues to obtain changes and exert their agency as citizens through organisations than on an individual basis.

Many women's issues in Albania today are in great need of intervention, so whoever can do something to improve the situation, be it through writing, signing petitions, showing up in the elections and so on, should just do it. In my own case, I think that in order for women's issues to be properly addressed, more organised action is needed. So, through this organisation that I have been leading for years now, I feel that I can undertake many more active citizenship activities than as a simple individual. However, the fact that I identify more with women's issues does not mean that I am limiting my activities only in this respect and that I am not an active citizen.

So, similarly to other women who are part of organisations or other civil society groupings, Tatjana associated agency with the organisation 
rather than with her personal potential as a citizen, recognising, however, that the umbrella of an organisation facilitated her work and empowered women more easily than in activities on individual basis.

\section{Conclusion}

This study analysed the narratives of women who exert their political citizenship through their agency in civil society or governmental decisionmaking bodies. Their openly described perceptions and practices of citizenship are used to create links between their narratives and the literature on gender and citizenship. The analysis evolves according to the findings of the women's narratives. In the first part of this study, women's perceptions of citizenship were openly analysed, presenting their concept associations in the same order of appearance as the interviews. Here they mainly conceptualised citizenship as closely linked to rights and duties, but also in terms of relationships between citizens and the state, as grounds for political citizenship action and so on. Secondly, this study analysed women's political citizenship practices and their own ways of expressing agency. Most of the women identified themselves as actors of change, but their situations, activities and experiences as political citizens were diverse. Thirdly, this paper briefly tackled important issues in women's activities as political citizens in Albania. 


\section{B Bibliography}

Lister, R., 1997. Citizenship: Feminist Perspectives. New York: New York University Press.

Lister, R. 2003. Feminist Theory and Practice of Citizenship. Annual conference of the DVPW (German Political Science Association), 1 January, Mainz.

Marshall, T. H., 1950. Citizenship and Social Class. Cambridge: Cambridge University Press.

Millen, D., 1997. Some methodological and epistemological issues raised by doing feminist research on non-feminist women. Sociological Research Online, 2(3).

Mouffe, C. 1992. Feminism, citizenship, and radical democratic politics. In J. Butler and J. W. Scott eds., Feminists Theorize the Political. New York: Routledge: 369 - 385.

Phillips, A., 1995. The Politics of Presence. New York: Oxford University Press.

Siim, B., 2000. Gender and Citizenship. Cambridge: Cambridge University Press.

Turner, B., 1990. Outline of a theory on citizenship, Sociology, 24(2): 189-218.

Voet, R., 1998. Feminism and Citizenship. London: Sage Publications.

Young, I. M. 1990. Justice and the Politics of Differences. Princeton, New Jersey: Princeton University Press.

Eriada Çela (eriada.cela@gmail.com) is a doctoral researcher at Tirana University, Faculty of Social Sciences in the Department of Pedagogy and Psychology. Her doctoral thesis deals with the gender perspective integration into the Albanian basic education curriculum as a prerequisite for democratic citizenship education. She graduated with a Master's Degree in Gender Studies at Central European University in Hungary. Since 2006, she is a lecturer at Aleksandër 
Xhuvani University in the Faculty of Human Sciences, Elbasan, Albania. Her interest in education, gender issues and active citizenship resulted in her participation in a number of international conferences and research paper publications. Additionally, she has worked as a local project coordinator with European Movement Albania for the following project: "The Reinforcement of Participatory Democracy and the Request for Institutional Responsibility by the Youth in Albania". 